\title{
Conservation Amid COVID-19 Pandemic: Ecotourism Collapse Threatens Communities and Wildlife in Morocco
}

\author{
SidiImad Cherkaoui ${ }^{1}$, Mohamed Boukherouk ${ }^{2}$, Tarik Lakhal ${ }^{3}$ Adil Aghzar $^{1}$, and Lahcen El Youssfi ${ }^{1}$ \\ ${ }^{1}$ Ecological Engineering and Natural Resource Management Research Group,Higher School of technology of Khenifra, BP 170 \\ Khénifra 54000Morocco, Sultan MlySlimane University, Morocco. \\ ${ }^{2}$ Laboratoire de recherches des sciences appliquées à l'environnement et au développement durable (SAEDD), High School of \\ technology of Essaouira, Cadi AyyadUniversity Marrakech, Km 9, Route d'Agadir, Essaouira Aljadida BP. 383, Morocco \\ ${ }^{3}$ Département des sciences de gestion, Faculté des Sciences Juridiques, Economiques et Sociales Agdal, Université, Mohammed V de \\ Rabat.
}

\begin{abstract}
COVID-19 pandemic has had huge impacts on multiple industries and sectors, not just ecotourism and wildlife protection in Morocco. Ecological health and wildlife are a critical resource for the country's tourism sector recovery. Conservation is considered as one of the industries that are hit hard by the COVID-19 pandemic. Many of the threats facing biodiversity and protected areas have been exacerbated during and following, the outbreak with practices such as poaching, wildlife trafficking, and forest logging activities resumed due to the country lockdown and ecotourism collapse. Conservationists should take emergency actions in the short-term to help rural communities and grassroots organizations and review waysto achieve conservation and sustainability goals in the post-pandemic era.
\end{abstract}

\section{Introduction}

Travel and tourism account for 10.3 percent of the country's global GDP [1], which makes the sector larger than agriculture. In 2019 alone, it created one in four new jobs [1]. The economic contribution of wildlife tourism is equally impressive. It came to US\$343.6 billion (0.4 percent of global GDP) in 2018[2]. Wildlife tourism supported 21.8 million jobs across the world, or 6.8 percent of total travel and tourism jobs [3]. The percentage is much higher in Africa, at a percentage of 36.3 percent [3].

Globally, ecotourism has been central to thousands of conservation projects that have generated jobs and income, empowering rural communities $[4,5]$. It has become a key argument in the "conserve or exploit" debate. The World Travel and Tourism Council (WTTC) estimates that up to 75 million jobs are at immediate risk, and anticipates an economic loss of up to US\$2.1 trillion lifted [6]. The recovery period after disease outbreaks has in the past averaged around 19.4 months- everything doesn't return to normal the day after the lockdown is lifted[6].In 2020, the World Economic Forum (WEF)[7] has ranked nature loss as one of the top global risks. COVID-19 has proved that nature loss and wildlife consumption are the root cause of the emergence of zoonotic infectious diseases, such as coronavirus, Ebola and HIV/AIDS [8]. Although they are quite different at first glance, they all originated from animal populations under conditions of severe environmental pressures[9].In addition, they all illustrate that destructive human behavior towards nature is endangering human health - a stark reality that was ignored for decades. Research indicates that most emerging infectious diseases and zoonotic spillover are driven by human activities $[10,11]$.

The tourism sector in Morocco is one of the important contributors to the economy of the country [12]. According to the Moroccan higher planning commission [13], its contribution to the GDP is $6.8 \%$ with an estimate of MAD 72.4 billion in 2017. But with the spread of the Coronavirus in the world the tourism industry got highly impacted as most of the countries are in the lockdown $[14,15]$. This has created a major downfall in the tourism sector including ecotourism $[6]$.

In this paper, a general commentary is made on the effect of the Coronavirus on the ecotourism sector in Morocco and its impact on rural dependent communities and conservation particularly in protected areas. In fact, many international as well as domestic flights in Morocco are forced to be canceled, as a result of the measures taken by the Moroccan authorities as a response to COVID-19 outbreak. Consequently, ecotourism and related activities are deemed to be entering into a great crisis also establishing socio-economic and conservation concerns. Incomes generating activities that are tightly linked to ecotourism are most affected as tourists are not able to visit Morocco. Also, 
conservation is also seen to be facing unprecedented threats as is seen in this context. The aim of this study is to shed light on the impact of the occurrence of corona virus on ecotourism, on dependent communities and on conservation especially in key Morocco's biodiversity areas.

\section{Ecotoursim as driver of incentive conservation}

Globally, ecotourism results in significant positive changes in perceptions and behaviors of local communities, both towards protected areas and Biodiversity $[16,17]$. In addition, many communities living near protected areas benefit from a share of tourism revenues. As the world emerges from the COVID-19 pandemic and undertakes the unprecedented task of repairing and stimulating national economies, investments in conservation could prove gamechanging for people and nature in many poor countries that are nonetheless rich in biodiversity [18].

Incentive-based conservation provides employment, ecological services, alternative incomes, health care, education, tourism, and project development [19]. Such approaches are based on the assumption that benefits derived directly from natural resources will encourage conservation and sustainable use of those resources [20,21]. Ecotourism has proven to improve conservation, awareness, attitudes, and increase pro-conservation behaviors [22, 23]. Community participation in conservation programs and the receipt of economic and social benefits may lead to improved conservation perceptions and approaches, which may, in turn, lead to pro-conservation attitudes [24, 25]. Reduction in negative behaviors (e.g. poaching) and an increase in positive behaviors (e.g. participation in conservation projects) can lead to positive conservation results (e.g. increased species densities and/or range; habitat improvement [26].

In Morocco, ecotourism is an effective means of enhancing protection by positively changing local perceptions, attitudes and behaviors towards wildlife and their natural habitats [27, 28]. It appears to play an important role in terms of the scale and scope of the conservation impacts [29]. However, although economic returns are important, they are not the main determinant of conservation outcomes and should not be the main metric used to assess conservation success of ecotourism sites[30, 24, 31]. Conservation practitioners are aware that even small scale ecotourism ventures can result in significant benefits for conservation $[32,33,34]$.

\section{Impact of COVID-19 on tourism in Morocco}

In Morocco, tourism has experienced exceptional performances during the last few years[35]. Ambitious projects have increased the beds capacity; increased flights connections and recreational ground activities. Tourism is an important provider of foreign currency and holds an important place in the Moroccan economy with a contribution of about $7 \%$ to GDP, more than 1 million jobs and 8 billion US\$ incomes in 2019[36]. Tourism is spreading throughout the faraway lands, benefiting from a surge in demand, the proximity of the markets that generate it and, above all, the impetus of the tourism strategy (Visions 2010 and 2020), which included sustainable tourism and nature tourism among its main guidelines[37].

Unfortunately, after this promising evolution during the two decades of the 2000 s, the cascading effect of the COVID-19 pandemic is crippling the Moroccan tourism and hospitality industry. Taking drastic security measures, Morocco closed its borders, suspended flights, and trips before declaring the lockdown on march $19^{\text {th }}$. Over a century tourism has never known such a catastrophic situation. The entire tourist chain is at a standstill and the entire activity is paralyzed. According to the National Tourism Confederation, the sector will have a shortage of $98 \%$ and about 3.2 billion Euros of loss [38].Tour operators, guides, transporters and restaurants... have seen their activities going to a sudden and abrupt halt.

In Marrakech, the first which concentrates $30 \%$ of hotels and more than $42 \%$ of tourism activity, the situation is dramatic. The car parks are crowded with vehicles, the hotels emptied, employees released, and services postponed. Elsewhere, in the hinterland and far from the traditional concentration touristy areas, the hiking trails are deserted as well as the lodges and guest houses. All the mountain guides, trek logistics providers lose their jobs and incomes. The considerable development of green tourism in Morocco is completely stopped. The efforts to save nature and raise awareness, which Morocco has deployed over the past decades, are abandoned for human security measures.

The decline in international tourism should continue until the end of the year. A situation that will depend on health and hygienic conditions in the world and the end of lockdown measures taken in the issuing countries, particularly in relation to the resumption of travel abroad. The situation in Morocco will have to suffer during a long period since the policies as well as the general panic will push tourists to focus on domestic travel and destinations nearby. Meanwhile, the debate and the adopted decisions are strictly economically and socially oriented. The main concerns of the government and the stakeholders are how to absorb the losses of months of paralysis and how to deal with the shortage. Efforts have thus focused on urgent social services to compensate for the losses of household incomes on the one hand and to allow tourism operators to deal with last-minute cancellations and their engagements during the lockdown. Although the confinement argues in favor of questioning the consumer society reality and its negative effects on the environment, reality shows a concentration on the economic impacts of COVID19 and less interest to sustainability, nature, and resources safeguarding considerations. 


\section{Impact of COVID-19 on wildlife and conservation in Morocco}

To better analyze the situation, we looked for information in court minutes, crime statements written by the Department of Water and Forestry and credible reports illustrated with photos that conservation NGOs shared on their websites or on different social media networks.

Indeed, from the Atlantic Moroccan Sahara to the Atlas Mountains, the COVID-19 outbreak has leveled a devastating blow to efforts to protect endangered wildlife in Morocco. For instance, in the Argan Arganaspinosa woodland steppes of Amzi in Tiznit area as well as in the Blue Cedar Cedrusatlantica forests of Middle Atlas, conservation work to protect some of Morocco's most important ecosystems and flagship species is facing a crisis following a collapse in ecotourism during the pandemic lockdown. The conservation authorities and Wildlife protection NGO have recently expressed concerns about the increasing death toll and trafficking of endangered species in Morocco. Some poachers and traffickers posted pictures of themselves holding poached animals, which they caught in several regions, on their social media account. These acts are widely condemned across the country by the Forest Department, NGO and public opinion.

Amid the pandemic, scientists have repeatedly urged humanity to reset its relationship with nature or suffer worse outbreaks $[39,40,41]$. But the economic consequences of the COVID-19 lockdown have raised fears of a surge in poaching, illegal fishing, and deforestation in life-sustaining ecosystems, with thousands of jobs in the ecotourism sector and related activities at risk across the country. The national focus now is on protecting human lives in this devastating pandemic. However, in many biodiversity hotspots and protected areas, socioeconomic impact is generally observed, particularly in areas where communities rely heavily on ecotourism for their livelihoods. According to conservancies in Morocco, grass roots organizations that depend on ecotourism to fund projects for endangered species and key habitats could be forced to close, after border closures and worldwide travel restrictions abruptly halted millions of dollars of incomes.

While poaching a particular animal may not escalate owing to the current suppression of travels and negative sentiments against animal products, illegal wildlife trafficking and poaching will go up if there is nobody to monitor activities within the protected areas and outside. In Anti-atlas, the Vulnerable Cuvier's Gazelle Gazellacuvieri, an endemic antelope of the Maghreb ecoregion[42], washeavy poached between March and Mayfollowing the collapse of the local tourism sector, according to the local populations. The Endangered Barbary Macaques Macacca Sylvanus, another endemic species of Morocco and Algeria[43], poaching has recovered it pace in High Atlas, in Eastern Rif region and possibly elsewhere. In Moroccan forested areas, thousands of song passerines were illegally caught while these species are breeding or migrating. Throughout the country European Bee-eaters (Meropsapiaster) are being heavily persecuted and killed by beekeepers who took advantage of the country lockdown to enhance persecution practices. This is also true for some apex and Morocco's highly threatened predators such as the African Golden Wolf Canisanthis, Honey Badger Mellovoracapensis and Stripped Hyena Hyenahyena[44]and raptors (Accipitridae, Falconidae) whose persecution and poisoning exacerbate as depredation the reaction of farmers. Moreover, shepherds are taking advantage of the country lockdown to bring their cattle in the protected areas where vegetation cover is generally better than in unprotected areas due to overgrazing and drought[45].

With regard to threatened Antelopes such as Cuvier's Gazelles, Mhorr gazelle Nangerdamamhor, Addax Addaxnasomaculatus, and Barbary sheep Ammotraguslevia, it could be years before these species can fully recover, increasing the risk that people come to rely on other activities to make a living, putting unsustainable pressure on natural resources[46, 47]. Additionally, it is harder to monitor land grabbing and illegal poaching. While the poaching of several species has continued during the lockdown (Table. 1), a recent report found that the illegal wildlife trade had been severely disrupted by movement and travel restrictions in Morocco (Cherkaoui obs. pers). Nevertheless, conservationists fear an explosion of illegal hunting if organizations are forced to lay off wildlife wardens and suspend surveillance programs.

In fact, poaching and wildlife trafficking already existed on a national scale even before the coronavirus outbreak $[48,49,50,51]$. Nevertheless, with more people out of work, the wild animals will be more appealing than animals sold by licensed animal shops. Then the right question here is the following: if the wardens/guides have no salaries, how will they effectively monitor human activities in and out of the protected areas?"Members of these communities may lose faith in wildlife conservation if there is no money forthcoming. In addition, people who live around Morocco's protected areas and looked forward to offering guidance to tourists may resort to other income-generating activities such as farming and fueling the never-ending human-wildlife conflicts as animals invade and destroy their livestock or new farms.

At several places across the country, we have recorded a spike in poaching activities, with animals killed between March and April 2020. More importantly, several grassroots and conservation organizations have experienced delays in funding during the pandemic. While wardens are forced to stay at home, illegal land grabbing and intentional wildfires increased in many places. For instance, there's rampant deforestation in Taza, Middle-Atlas, High Atlas and Rif Mountains that rose sharply when the Moroccan government decreed health containment in early March of this year. The pandemic has not helped because there are apparently fewer patrols and rangers in the field. In the contrary, illegal loggers as well as poachers, who obviously do not care about coronavirus, saw their activity increase widely under the conjugated effect of protected areas surveillance drop. 


\section{Discussion}

Sustainable and wildlife tourism is an increasing contributor to economic activity around the world.The global benefits of conservation from ecotourism have been well documented [52]. Community-based conservation areas in particular provide income support for families through a share in tourism-derived income. Also, the mere existence of species-rich landscapes provides the public opportunities to visit the national parks and preserves [53]. A number of ecosystem services are provided by global biodiversity $[54,55]$. Indeed, vast quantities of carbon stored in trees and soils act as a natural hedge against climate change [56]. Existing and potential use of natural products for medicinal purposes is huge [57]. Further, wild species, from the largest to the microscopic, interact in ways that keep up delicaterunning natural cycles-whether the provision of fresh water or fertile soil - that make Planet Earth habitable for humans [58]. Biodiversity provides transboundary benefits, and that not all countries can meet the costs of its conservation, it is in the interests of the world to share in the costs $[58,60]$.

Success would depend on investments that simultaneously reinforce the impact of conservation and mitigate or reduce wildlife trafficking and poaching activities; providing capital preservation and/or returns on investments and generating cash flows through sustainable use of nature by local communities [60]. In addition tothis, both to protect wild animals and to reduce the possibility of a new pandemic like COVID-19, scientists should emphasize the importance of stopping illegal wildlife trafficking, closing wildlife markets, and protecting natural habitats.

In Morocco, protected areas are generally underfunded, resulting in insufficient funds to support communities living closest to key ecosystems and nature [62]. As a result, communities often pursue land-use practices that provide for their immediate needs, but which may undermine wildlife conservation [63]. However, when local communities have enough support, they look after the land and its biodiversity [64]. This is apparent in Morocco's national parks, reserves, and other country's biodiversity hotspot areas[62, 63]. Moreover, the ecotourism activities in Morocco dropped significantly during the Covid-19 lockdown which affected the generating income activities, seasonal employments and green jobs provided by this sector as the tourism companies associated with outbound tourism faces severe loss. Part of rural economy inside and nearby protected areas is largely reliant on the ecotourism sector and every year a significant amount of global tourists come to visit the important biodiversity destinations in Morocco [65].

In business, COVID-19 has prompted increased discussion of the importance of diversified incomes and resilient supply chains. Therefore, a fundamental lesson from the current outbreak situation is that conservancies should not overly reliant on one source of income. Development of inclusive finance models such as small loans for rural communities can be a further option to promote diversified sustainable livelihood opportunities in local economies, minimizing the risk of relying on a specific sector or resource. Besides, wildlife protection in Morocco should be from now onward everybody's best interest for sustainable future and resilient rural communities and landscapes. Currently, there are even more pressing reasons to invest in communities that protect nature through wildlife tourism and conservation. COVID-19 recovery packages must include this investment in public policy. Nature underpins people's survival, wellbeing and, sustainable development.

Moreover, ecotourism will undergo great changes as it is the case for all aspects of human life. As we can already see, hygienic concerns are surfacing and should help to reshape the face of the trip by taking into consideration parameters such as social distancing, cleanliness, respect for other tourists and destinations. The conservative approach will undoubtedly be enriched with new measures and should make it possible to better protect species and resources more. General awareness should be established and the concerns about the well-being of the population and the species will gain more and more. The challenge is to be able to manage this period of emptiness between confinement and the start of travel, which will last a long time. The different ecotourism and conservationist actors must mobilize to manage several facets of the crisis.

\section{Conclusion and perspectives}

In the light of COVID-19 outbreak and its impact on Ecotourism sector and biodiversity conservation in Morocco, it is crucial to anticipate on the post-crisis situation. While many revival plans are now being considered by the various tourism organizations, conservation authorities in the country as well as NGOs and communities working in ecotourism must be more proactive and think about a real plan for the transformation of Moroccan tourism which has to take into account the ecological and environmental stakes. The challenge is no longer to seek only the growth of tourism only, but to seek the development of ecotourism with positive impacts on the environment and conservation. It will be a question of finding a balance between the preservation of ecosystems and economic realities.

The COVID-19 outbreak is an opportunity to review priorities and rethink tourism policies for the development of a new tourism model by mainstreaming ecotourism component for sustainability education and conservation. We suggest the following measures to be taken as urgently as possible:

1) To reflect on a new plan for the transformation of tourism by capitalizing on the unprecedented experiences of eco-tourism as a solution the for climatic and health crises;

2) To support rural tourism as a strategy that helps to anchor rural communities in their territory and thus promote the socio-economic development of the hinterland;

3) To promote nature-based solutions; 
4) To raise more fund and support to conservation projects and grassroots communities that might favor combating poaching, overgrazing and habitat destruction through a win-win situation;

5) To accelerate the processes of classification of new protected areas or the extension of the surface of the existing ones;

6) To create a new participatory approach, integrating the local population protected areas and natural resources co-management;

7) To promote environmental-friendly agricultural practices such as permaculture, agro-tourism, and organic farming;

8) To Set up a financial contribution (Green tax) on tourism products (transport, catering, accommodation, etc.) to finance ecotourism activities and conservation;

9) To support tourism professionals and stakeholders to develop sustainable tourism packages;

10) To put in place adapted and easily accessible financing tools to enable the resilience of sustainable tourism professionals (accommodation providers, guides, producers, etc.) in the event of a crisis and outbreaks,

11) To maintain or, ideally, increase the, increasing ranger numbers will be critical to ensure that protected areas and valuable species are adequately protected;

12) To promote environmental education in order to inculcate in future generations the economic, social, cultural and environmental importance of nature conservation; and

13) To make an evaluation of public policies on the basis of species and nature conservation indicators.

This being said, stopping natural habitat destruction, poaching, illegal possession and illegal trade of wildlife has become, more than ever, a global priority to prevent zoonosis, such as the virus causing COVID19 or other diseases spillover between wild animals and humans. Moreover, it is crucial to ensure the balance of ecosystems, halt the loss of biodiversity and increase the capacity of humankind to cope with and adapt to climate change.

\section{References}

1. World travel tourism council (WTTC), Travel and tourism economic impact, March, (WTTC report, 2019a)

2. Word Bank Group (WBG), Supporting Sustainable Livelihoods Public Disclosure Authorized through Wildlife Tourism. Knowledge Series, Tourism for Development, (Washington, DC 20433, USA, 2018)

3. World travel tourism council (WTTC), The economic impact of global wildlife tourism, (WTTC report, 2019b)

4. S. Farber, R. Costanza, D. Childers, J. Erickson, K.Gross, M. Grove, et al,Bio. Sci.,56 (2006)

5. A. Stronza, A. C. Hunt, A. C. and Fitzgerald, L. A Ann. Rev. Environ. Res. 44 (2019)

6. World travel tourism council (WTTC), Only the G20 can drive forward a coordinated recovery response to the COVID-19 crisis says WTTC (2020)

7. World Economic Forum (WEF), Nature Risk Rising: Why the Crisis Engulfing Nature Matters for Business and the Economy. Geneva Switzerland(2020)

8. K.E. Jones, N.G.Patel, M.A.Levy, A.Storeygard, D.Balk, J.L.Gittleman, P.Daszak,.Nature451 (2008)

9. J.A. Patz, P. Daszak, G.M. Tabor, A.A. Aguirre, M. Pearl, J. Epstein, , E. Disease, Env.Heal.Persp., 112 (2004)

10. R.K. Plowright, C.Parrish, H.McCallum, P.J.Hudson, A.Ko, A.Graham, J.Loyd-Smith, Nat. Rev.Microb., 15(8): 502-510(2017)

11. C.L.Faust, , H.I.McCallum, L.S.P. Bloomfield, N.Gottdenker, T.R.Gillespie, C.J.Torney, A.P.Dobson, R.K. Plowright, Ecol. Lett., 21 (2018)

12. K. Harrou, Tableau de bord sectorial de l'économie marocaine, Ministère de l'Economie et des Finance. Rabat, Morocco (2019)

13. Haut Commissariat au Plan (HCP) www.hcp.ma Site institutionnel du Haut-Commissariat au Plan. Site de l'Observatoire du Tourisme Baromètres de l'activité touristique (2017)

14. M. Chinazzi, J. T. Davis, M. Ajelli, C. Gioannini, M. Litvinova, S. Merler, C. Viboud, Science. 368 (2020)

15. Daily Ft. Tourist arrivals fall $17.7 \%$ in Feb. Retrieved from aily FT. 2020. Tourism industry meets to assess COVID-19 impact, way forward (2020)

16. N.M. Ardoin, M.Wheaton, A.W.Bowers, C.A.Hunt, W.H.Durham, J. Sust. Tour.23 (2015)

17. R.Buckley, Ecological indicators of tourist impacts in parks. J. of Ecot., 2 (2003b)

18. UNTWTO (2020)

19. A.Spiteri, S.K.Nepal, Envi.Manag.37, 1-14 (2006).

20. B. B. Bynum, G. T.Green, Ecotourism and natural resource conservation: the 'potential' for a sustainable symbiotic relationship, J. of Ecot. (2015)

21. A. Stronza,The economic promise of ecotourism for conservation. J. Ecot.6(3):210-30 (2007)

22. R.C. Buckley, J.G. Castley, deVasconcellos, F. Pegas, A.C. Mossaz, R. Steven, Plos One 7 (2012)

23. J.Coria, E.Calfucura. Ecol. Econ.73:47-55 (2012)

24. C.J. Stem, J.P. Lassoie, D.R.Lee, D.D.Deshler, J.W.Schelhas, Soc. Nat. Resour. 16 (2003)

25. F.V. Pegas, A.Coghlan, A. Stronza, V. Rocha, J..Ecot.12(2013) 
26. C.M.Holmes, Oryx,37:305-315 (2003)

27. F.ARIB, Téoros, 24 (1), 37-41.(2005)

28. Y.Lamnadi, Signs of hope or wrong way? The implementation of ecotourism as a touristic product within Morocco destination. In: Blàzquez, M., Mir-Gual, M., Murray, I. y Pons, G.X. (eds.). Turismo y crisis, turismocolaborativo y ecoturismo. XV Coloquio de GeografíadelTurismo, el Ocio y la Recreación de la AGE. Mon. Soc. Hist. Nat. Balears, 23: 357-367. SHNB-UIBAGE. ISBN 978-84-617-5115-0 (2016)

29. L.Sbai, Evaluation du cadre juridique et institutionnel relatif à l'écotourisme et aux aires protégées au Maroc. Rapport UICN (2012)

30. A.Blamford, A. Bruner, P. Cooper, R. Costanza, S. Farber, R. Green, et al,.Science, 297 (2002)

31. T.P. Romero-Brito, R.C. Buckley, J. Byrne, Plos One11 (2016)

32. K. Lindberg, Economic aspects of ecotourism. In K. Lindberg, M.E. Wood, and D. Engeldrum (eds). Ecotourism: a guide for planners and managers. Volume 2. Washington, D.C. The Ecotourism Society. 87-117. (1998)

33. H. K.Cordell, M.Bowker,The global economic contribution of protected natural lands and wilderness through tourism. (The Wild Planet Project, May 2007, 2007)

34. C.A.Hunt, W.H.Durham, L.Driscoll, M.Honey, J. Sustain. Tour. 23(3):339-57 (2015)

35. I. Aberrhaze, Tourisme et artisanat du 03 au 07 Décembre 2018. Portail du Centre National de Documentation du Maroc (2019), Consulté le 22 octobre 2019.

36. Ministère du tourisme, Tourisme en chiffres (2020) www.tourism.gov.ma

37. M. Boukherouk, A.Tlidi, Tourisme, in Noureddine El Aoufi et Bernard Billaudot (Dir), Made in Maroc Made in Monde, Profils sectoriels et émergence industrielle, Economie critique, 2019, Rabat Volume 3p 343-380 (2019)

38. B. Berrisoule, Coronavirus - Tourisme : Les professionnels comptent leurs pertes, l'Economiste, Edition $\mathrm{N}^{\circ}: 5721$ Le 18/03/2020 (2020)|

39. World Health Organzation (WHO) Managing Epidemics: Key facts about major deadly diseases," World Health Organization (2018). P. M. White, others, spending at least 120minutes a week in nature is associated with good health and wellbeing," Scientific Reports 9 (2019):

40. C. K. Johnson, others, Proc. R. Soc. B. 287 (2020)

41. IUCN SSC Antelope Specialist Group. Gazellacuvieri. The IUCN Red List of Threatened Species 2016: e.T8967A50186003 (2016)

42. T.M. Butynski, J. Cortes, S. Waters, J. Fa, M.E. Hobbelink, E. van Lavieren, F. Belbachir, F. Cuzin, K. de Smet, M. Mouna, H. de Iongh, N. Menard, A.Camperio-Ciani, Macacasylvanus. The IUCN Red List of Threatened Species 2008: e.T12561A3359140 (2008)

43. S. Aulagnier, F. Cuzin, M. Thévenot (Eds.). 2017 Mammifères sauvages du Maroc. Peuplement, répartition, écologie, Société française pour létude et protection des mammifères, Paris (2017)

44. S.I. Cherkaoui, S. Selmi, Z. Amhaouch S. Hanane, J. of Env. Ass. 190 (2018)

45. F.Cuzin, E. Cuzin, A. Sehhar, T. Wacher, Etude pour l'élaboration de lignes directrices et d'un plan d'action stratégique pour la conservation des ongulés au Maroc. Vol. 1, rapport principal. Haut-Commissariat aux Eaux et Forêts et à la Lutte Contre la Désertification (HCEFLCD), Projet de Gestions des Aires Protégées (PGAP) et Banque Mondiale, Global Environment Facility (GEF) (2007)

46. T. Abaigar, E.Rodríguez-Caballero,C. Martinez,Z Amhaouch,L. M. Samlali,F. Aparicio,T. EL Bella, A. Essalhi,J. Fernandez,J. Garcia,J. Haya,A. M’Bareck,H. M’Bareck,M. L. Gonzales, F. de Larrínoac. Glob. Ecol. and Cons. 19(2019)

47. A. Shipp, Traff. Bull.19: 65 (2002)

48. E. van Lavieren, .Traff. Bull. 21 (2008)

49. E. Martin,C. Perry-Martin, Swara (Jul-Sep): 16-29 (2012)

50. D. Bergin, V.Nijman, Ongoing, Traff. Bull.26 (2014)

51. C.Wardle, R.Buckley, A. Shakeela, and J.G.Castley, Journ. of Ecot. ((2018)

52. J.J.VASKE, Survey Research and Analysis: Applications in Parks, Recreation and Human Dimensions. Venture Publishing, State College, USA (2008)

53. B.J.Anderson, P.R.Armsworth, F.Eigenbrod,.J. Appl. of Ecol.46 (2009)

54. S.Quijas, P.Balvanera,Biodiversity and Ecosystem Service. In: Levin S.A. (ed.) Encyclopedia of Biodiversity, second edition, Volume 1, pp. 341-356. Waltham, MA: Academic Press.52013 ${ }^{\circ}$

55. F.de Bello, S. Lavorel, S. Diaz, et al,Biod. and Conses.19 (2010)

56. B.J.Cardinale, K.L.Matulich, D.U.Hooper,et al..Amer. J. Bot.98 (2011)

57. P.Balvanera, A.B Pfisterer,N.Buchmann,Ecol. Lett.9: 1146-1156 (2006)

58. R. Costanza, R. d'Arge, R. De Groot, S.Farber, M. Grasso, B. Hannon, et al, Nature, 387, 253-260 (1997)

59. D.Li Yong, A.Jain, , Y.Liu, , M.Iqbal, C.Y.Choi, N.J.Crockford, S.Millington, J.Provencher, Cons. Biol., 32 (2018)

60. C.G. Sandbrook, Conserv. Lett. 3 (2010) 
61. M. Ribi, International Workshop on sustainable tourism in Moroccan Protected Areas, Waters and Forests Department. pp. 56 (2007)

62. Global Environment Facility (GEF), Morocco Protected Areas -Management Project. The World Bank 19917. Washington, USA. (2010)

63. M. El-BekkaY, A. Moukrim, F. Benchakroun, AJEST, Vol. 7(6), pp. 441-447 (2013)

64. N. Roudiad,Vision 2020 for tourism in Morocco Focus on Sustainability and Ecotourism. Expert Group Meeting on Ecotourism, Poverty Reduction \& Environmental Protection. Rabat, Morocco (2013) 
Table. 1.List of wildlife suffering from poaching and trafficking toll rise as reported from conservation groups in Morocco.Data collected between 01 March and 31 May 2020

\begin{tabular}{|c|c|c|c|c|}
\hline Species or group of species & $\begin{array}{c}\text { IUCN } \\
\text { Statu } \\
\mathbf{s}\end{array}$ & $\begin{array}{l}\text { Protecte } \\
\quad \text { d }\end{array}$ & $\begin{array}{c}\text { Region } \\
\text { in } \\
\text { Morocc } \\
\text { o }\end{array}$ & $\begin{array}{l}\text { Numberreporte } \\
\text { d }\end{array}$ \\
\hline "Macacca Sylvanus Barbary Macaques & $\overline{\mathbf{E N}}$ & Yes & $\begin{array}{l}\text { N.E, } \\
\text { H.A }\end{array}$ & 3 \\
\hline HyaenahyaenaStripped hyena & NT & Yes & N.E & 2 \\
\hline Canisanthus African golden wolf & $\mathrm{LC}$ & No & A.S; S.E & 13 \\
\hline Genettagenetta Common Genet & LC & No & All & 18 \\
\hline Mellivoracapensis Honey Badger & $\mathrm{LC}$ & Yes & S.A & 1 \\
\hline Herpestes ichneumon Egyptian Mongoose & $\mathrm{LC}$ & No & All & 22 \\
\hline MustelanivalisLeast weasel & $\mathrm{LC}$ & No & All & 10 \\
\hline Vulpeszerda Fennec Fox & $\mathrm{LC}$ & Yes & S.E & 3 \\
\hline VulpesvulpesRed Fox & $\mathrm{LC}$ & No & All & $>50$ \\
\hline FelislybicaLybian wild Cat & $\mathrm{LC}$ & No & S.A & 3 \\
\hline Gazellacuvieri Cuvier's Gazelle & VU & Yes & A.A & 11 \\
\hline dorcas gazelle Gazelladorcas & VU & Yes & A.S & 2 \\
\hline Ammotraguslevia Barbary Aoudad & VU & Yes & S.E & 3 \\
\hline Lepus mediterraneus Maghreb Hare & $\mathrm{LC}$ & No & All & $>500$ \\
\hline AtelerixalgirusAlgerian hedgehog & $\mathrm{LC}$ & Yes & All & $>500$ \\
\hline Chiroptera & & Yes & All & $>500$ \\
\hline AtlantoxerusgetilusAtlas ground squirrel & $\mathrm{LC}$ & No & C.A & $>1000$ \\
\hline Testudo graeca Common Tortoise & $\mathbf{V U}$ & Yes & All & $>1000$ \\
\hline $\begin{array}{l}\text { Uromastyxnigriventris/UromastyxacanthinuraMorocca } \\
\mathrm{n} \text { spiny-tailed lizard }\end{array}$ & NA & Yes & S.E & $>500$ \\
\hline ChamaeleochamaeleonCommon Chameleon & $\mathrm{LC}$ & Yes & All & $>500$ \\
\hline Najahaje Egyptian cobra & NA & Yes & A.S & 6 \\
\hline BitisarietansPuff adder & $\mathrm{LC}$ & Yes & C.A, A.S & 8 \\
\hline Varanusgriseus Desert Monitor & $\mathrm{LC}$ & Yes & A.S, S.E & 4 \\
\hline Bubo ascalaphusPharaoh Eagle-Owl & $\mathrm{LC}$ & Yes & $\begin{array}{l}\text { N.E, S.E, } \\
\quad \text { A.S }\end{array}$ & 12 \\
\hline Buteocirtensis Maghreb Buzzard & $\mathrm{LC}$ & Yes & All & 7 \\
\hline Falco biarnicusLanner Falcon & $\mathrm{LC}$ & Yes & S.A & 2 \\
\hline Other raptors & & Yes & All & $>50$ \\
\hline Alectoris Barbara Barbary Partridge & $\mathrm{LC}$ & No & All & $>100$ \\
\hline StreptopeliaturturTurtle dove & $\mathbf{V U}$ & Yes & All & $>500$ \\
\hline UpupaepoposCommon Hoopoe & $\mathrm{LC}$ & Yes & All & $>500$ \\
\hline MeropsapiasterEuropean Bee-eater & $\mathrm{LC}$ & No & All & $>1000$ \\
\hline Golden finchCardualiscardualis & $\mathrm{LC}$ & Yes & All & $>1000$ \\
\hline Other song birds & & & All & $>1000$ \\
\hline
\end{tabular}

A.A $=$ Anti-tlas; $\mathrm{AS}=$ Atlantic Moroccan Sahara; C.A $=$ Central Atlantic; $\mathrm{EN}=$ Endangered, HA= High Atlas; IUCN= International Union for Conservation of Nature; LC= Least Concern; M.A= Middle Atlas; NA= Not Assessed; N.E= North-Eastern; NT=Near Threatened; SE= South Eastern; VU= Vulnerable, 